\title{
LAWS AND POLITICS OF THE INTERNATIONAL RELATIONS OF JAPAN AND THE UNITED STATES
}

\author{
Makitaro Hotta, published jointly by the School of International Service, \\ American University, Washington, the College of International \\ Relations, Ritsumeikan University, Kyoto, 1996 Pp 195. \\ Noted by A H Angelo*
}

This is a compendium of documents and materials relating to Japan and United States relations from the Cairo Declaration of 1 December 1943 to the Japan/US Joint Declaration on Security Alliance for the 21st Century of 17 April 1996. The collection runs chronologically and includes many documents that are not found in the more general collections of Japanese historical documents. ${ }^{1}$ The source of the documents are various English language records of the USA.

The materials will serve a great number of purposes: they can be used for comparative law classes and for international relations programmes, for constitutional law teaching and for aspects of public international law. The documents provide a great stimulus to thought and a sound basis for discussion. Depending on the use to which they are put, they may usefully be supported by further documents. For instance, the policy statement of 27 March 1947 on education could interestingly be compared with the Imperial Rescript on Education which it effectively superseded. ${ }^{2}$ Further, in some contexts it would be useful also to have the Imperial Rescript of 14 August 1945 which accepted the Potsdam Declaration and which preceded that which announced the surrender on 2 September $1945 .^{3}$

* Professor of Law, Victoria University of Wellington.

1 D J Lu Sources of Japanese History 2 vols (McGraw-Hill, New York, 1974) especially ch XIV and ch XVII.

2 Rescript on Education of 30 October 1890; see Lu above n 1, vol 2, 70.

3 See Lu above n 1, vol 2, 176. This is the document known in English for its telling phrases: "Despite the best that has been done by everyone ... the war situation has developed not necessarily to Japan's advantage, while the general trends of the world have all turned against her interest"; "... it is according to the dictates of time and fate that we have resolved to pave the way for a grand peace for all generations to come by enduring the unendurable and suffering what is insufferable". 
The documents in the collection are presented without commentary. There is, however, much commentary available elsewhere written by those involved in the particular events, and also by those with access to these and related documents if commentary is required. This particular collection facilitates the access of others to the historical material and assists them in forming their own views of recent critical world events. In Japanese constitutional terms, the documents presented are relevant for instance to the status of the Emperor in the post-1946 period, to the maintenance of military forces by Japan, and to the Northern Territories issues. ${ }^{4}$ More generally, the documents enable greater appreciation of the specific development of the 1946 Constitution from the Potsdam Declaration through to the final text of 3 November 1946.

Professor Hotta is to be commended for the compilation of this most worthwhile collection.

4 The contemporary context gives the issues a different aspect, nevertheless the Northern Territories, and article 9 of the Constitution remain the subject of debate in Japan and outside Japan. It is interesting that 50 years from the end of World War II, the key international players (except for the United Kingdom) and many of the substantive issues remain the same. 